\title{
Virulence of Aeromonas hydrophila and some other bacteria isolated from European eels Anguilla anguilla reared in fresh water
}

\author{
Consuelo Esteve, Elena G. Biosca, Carmen Amaro \\ Departamento de Microbiología, Facultad de Ciencias Biológicas, Universidad de Valencia, E-46100 Burjassot, Spain
}

\begin{abstract}
Studies were conducted to determine the pathogenicity for European eels Anguilla anguilla and rainbow trout Oncorhynchus mykiss of several strains of the species Aeromonas hydrophila, A. jandaei, A. sobria, A. caviae, Plesiomonas shigelloides, Vibrio anguillarum, Pseudomonas fluorescens and Shewanella putrefaciens isolated from an eel farm. Virulence of 20 isolates obtained during epizootics from diseased eels, asymptomatic carriers and tank water and of 20 isolates obtained during the absence of disease from healthy eels and water was evaluated by 2 challenge methods: intraperitoneal injection (IP) and bath exposure. Of the isolates tested by IP, all strains of $A$. hydrophila, and those of $A$. jandaei mainly from epizootics, were pathogenic for eels ( $\mathrm{LD}_{50}$ dose $10^{5.4}$ to $10^{7.5} \mathrm{cfu}$ $\mathrm{fish}^{-1}$ ). Strains of these species caused an ulcerous disease by bath exposure to $10^{7}$ to $10^{8} \mathrm{cfu} \mathrm{m}^{-1}$. In contrast, rainbow trout were less susceptible to infection caused by $A$. hydrophila and $A$. jandaei isolates, perhaps because of the lower water temperatures at which they were held during challenge. The epizootics in the eel populations occurred in spring and summer when water temperatures were 17 to $22^{\circ} \mathrm{C}$. The data indicate that $A$. hydrophila and A. jandaei are European eel pathogens and that infections may occur by waterborne transmission. Therefore, the presence of these bacteria in the farm environment probably constitutes a health hazard for eels.
\end{abstract}

\section{INTRODUCTION}

Epizootics caused by obligate pathogens such as Pseudomonas anguilliseptica and Vibrio vulnificus biotype 2 have been reported in cultured European eels Anguilla anguilla (Nakai \& Muroga 1982, Biosca et al. 1991, Michel \& Bernardet 1991). However, there are cases of disease in which other bacteria seem to be implicated (MacCarthy 1976, Jensen et al. 1983, Mellergaard \& Dalsgaard 1987, Esteve \& Garay 1991).

In a previous study, 3 disease outbreaks were recorded in an eel farm located in Valencia (Spain) during spring and summer 1987 and 1988 when water temperatures were 17 to $22^{\circ} \mathrm{C}$ (Esteve \& Garay 1991). The disease in these outbreaks resembled 'red fin disease' of Japanese eels (Rickards 1978) with regard to external lesions, mortality rates and seasonal pattern. Losses were high ( $80 \%$ ) when glass eels in the initial stages of feeding were involved. These losses were economically important because eel production depends on the availability of 'seed' from nature. The mortality occurring in silver eels (adults) was lower (approximately $30 \%$ ). Eels were treated with tetracycline ( $40 \mathrm{mg} \mathrm{kg}^{-1}$ of fish) for $7 \mathrm{~d}$, and mortality decreased. Aetiology of the disease was complex. The following bacterial species were isolated on tryptic soy agar plus $1 \%(\mathrm{w} / \mathrm{v}) \mathrm{NaCl}$ (TSA-1) from freshly dead eels: (1) motile Aeromonas spp. (A. hydrophila and A. jandaei), (2) Pseudomonas fluorescens and (3) Shewanella putrefaciens. Although these species were also present in samples from routine surveys (tank water/healthy eels), their levels in the routine surveys were different from those observed during epizootics. On the other hand, the species A. sobria, Vibrio anguillarum and Plesiomonas shigelloides, which are described as potential fish pathogens (Austin \& Austin 1987), were mainly isolated on TSA-1 from healthy eels and their surrounding water.

The present work was a continuation of the study started by Esteve \& Garay (1991). Its objective was to determine the virulence of the bacterial species (Aeromonas hydrophila, A. jandaei, A. sobria, A. caviae, 
Plesiomonas shigelloides, Vibrio anguillarum, Pseudomonas fluorescens and Shewanella putrefaciens) isolated from the affected European eel farm during epizootics as well as during routine surveys, so that their importance as European eel pathogens could be assessed

\section{MATERIAL AND METHODS}

Experimental fish. The infectivity study was conducted using juvenile European eels Anguilla anguilla (elvers) (5 to $12 \mathrm{~g}$ ) and rainbow trout Oncorhynchus mykiss $(4 \mathrm{~g})$. Groups of 6 fish (elvers or trout) were transferred to 24 l plastic tanks supplied with dechlorinated municipal water. Water temperatures were optimal for these fish, ranging from 20 to $22^{\circ} \mathrm{C}$ for elvers and from 13 to $15^{\circ} \mathrm{C}$ for trout. Effluent water from the tanks was treated with sodium hypochlorite in sufficient concentration to kill pathogens present. Tanks were treated with $0.1 \mathrm{~N}$ HCL and irradiated with ultraviolet light when the experiment was over.

Challenge bacteria. A number of strains of the species Aeromonas hydrophila (10), A. jandaei (8), A. sobria (4), A. caviae (3), Plesiomonas shigelloides (2), Vibrio anguillarum (4), Pseudomonas fluorescens (7) and Shewanella putrefaciens (2) were evaluated for their virulence (see Tables $2 \& 3$ ). The number of isolates tested for each species approximately reflected the numerical relationship previously observed among these species (Esteve \& Garay 1991). Oxidative bacilli ( $P$. fluorescens and $S$. putrefaciens) were identified using the tests reported by Palleroni (1984) and Thampuran \& Lyer (1989). Fermentative bacilli (Aeromonas spp., $V$, anguillarum, and $P$. shigelloides) were classified by a numerical taxonomy study (Esteve \& Garay 1992). Some biochemical characteristics of the strains tested are given in Table 1.
For challenging, previously lyophilized strains were used.

Challenge. IP challenge: Bacterial strains were grown overnight on TSA-1 at $25^{\circ} \mathrm{C}$. For each strain, 6 fish (elvers or trout) were injected intraperitoneally (IP) with $0.1 \mathrm{ml}$ of a suspension containing $10^{9}, 10^{8}, 10^{7}$, $10^{6}, 10^{5}$ and $10^{4}$ cells $\mathrm{ml}^{-1}$ in phosphate-buffered saline (PBS, pH 7.0). Six fish (controls) injected with $0.1 \mathrm{ml}$ of sterile PBS were held under the same conditions as the challenged specimens. Mortalities were recorded daily for $7 \mathrm{~d}$ (Santos et al. 1988). Liver and kidney samples from freshly dead fish were cultured on TSA-1, and isolates were subsequently tested for their biochemical properties (see Table 1). Mortalities were only considered if the injected bacterium grew in pure culture from these samples. For each strain, the $50 \%$ lethal dose $\left(\mathrm{LD}_{50}\right)$ was calculated by the method of Reed \& Müench (1938). According to Santos et al. (1988), strains that exhibited $\mathrm{LD}_{50} \geq 10^{8} \mathrm{cfu} \mathrm{fish}^{-1}$ were considered avirulent.

Bath challenge: Only the most virulent strains in IP experiments were selected for bath challenges (see Table 4). Strains were grown for $24 \mathrm{~h}$ in tryptic soy broth (Oxoid) supplemented with $1 \% \mathrm{NaCl}$ (TSB-1). For each strain, duplicate groups of 6 elvers (average weight $12 \mathrm{~g}$ ) were held for $60 \mathrm{~min}$ in an aerated bath (6 l) containing 2 and $20 \mathrm{ml}$ broth culture $\mathrm{l}^{-1}$ and then returned to their tanks (Markward \& Klontz 1989). Fish were exposed to $10^{7}$ and to $10^{8}$ cells $\mathrm{ml}^{-1}$ during each treatment. Mortalities were recorded daily for $14 \mathrm{~d}$ (Baxa et al. 1990). Samples from ulcers, livers, and kidneys of freshly dead elvers were examined for the presence of the challenge bacterium. At $14 \mathrm{~d}$ postexposure, samples of gills, liver and kidney from all survivors were also analyzed.

Statistical analysis. The association between virulence for eels and origin of the isolates (epizootics/nonepizootics) was assessed using the Chi-square $\left(\chi^{2}\right)$ test.

Table 1. Biochemical characteristics of the Gram-negative, oxidase-positive and motile bacterial species that were tested for virulence. 1: $\mathrm{O}$ (oxidative)/F (fermative); 2: colony pigment; 3 : pyoverdines production ${ }_{i} 4: \mathrm{H}_{2} \mathrm{~S}$ production from thiosulphate 5: gelatinase; 6 : DNase; 7 : growth at $42{ }^{\circ} \mathrm{C}_{i}$ 8: O/129 test $(150 \mu \mathrm{g})$ (R: resistant; S: sensitive); $9:$ growth with $0 \% \mathrm{NaCl}_{i} 10: \mathrm{growth}$ with $6 \% \mathrm{NaCl}_{i}$ 11: arginine dihydrolase $(\mathrm{ADH})$; 12: ornithine decarboxylase (ODC); 13: Voges-Proskauer; 14: acid production from salicin; 15: esculin hydrolysis; 16 : elastin hydrolysis; 17 sulphatase; 18 ; gas production from glucose. $(+)$ All isolates were positive; (-) all isolates were negative; $v$ : variable response ( 20 to $80 \%$ of isolates were positive)

\begin{tabular}{|c|c|c|c|c|c|c|c|c|c|c|c|c|c|c|c|c|c|c|}
\hline Species & 1 & 2 & 3 & 4 & 5 & 6 & 7 & 8 & 9 & 10 & 11 & 12 & 13 & 14 & 15 & 16 & 17 & 18 \\
\hline Aeromonas hydrophila & $\mathrm{F}$ & - & - & - & + & + & $\mathrm{v}$ & $\mathrm{R}$ & + & - & + & - & + & + & + & + & - & + \\
\hline Aeromonas jandaei & $\mathrm{F}$ & - & - & - & + & + & + & $\mathrm{R}$ & + & - & + & - & + & - & - & $\mathrm{v}$ & $\mathrm{v}$ & + \\
\hline Aeromonas sobria & $\mathrm{F}$ & - & - & - & + & + & $\mathrm{v}$ & $\mathrm{R}$ & + & - & + & - & $\mathrm{v}$ & - & - & - & - & + \\
\hline Aeromonas caviae & $\mathrm{F}$ & - & - & - & + & + & + & $\mathrm{R}$ & + & - & + & - & - & + & + & - & - & - \\
\hline Plesiomonas shigelloides & $\mathrm{F}$ & - & - & - & - & - & + & $\mathrm{S}$ & + & - & + & + & - & - & - & - & - & - \\
\hline Vibrio anguillarum & $\mathrm{F}$ & - & - & - & + & + & - & $\mathrm{S}$ & + & + & + & - & $\mathrm{v}$ & - & + & + & - & - \\
\hline Pseudomonas fluorescens & 0 & - & + & - & + & - & - & $\mathrm{R}$ & + & - & + & - & - & - & - & - & - & - \\
\hline Shewanella putrefaciens & 0 & + & - & + & + & + & - & $\mathrm{R}$ & + & - & - & - & - & - & - & - & - & - \\
\hline
\end{tabular}




\section{RESULTS}

\section{IP challenges}

Of the isolates recovered during epizootics only those of the species Aeromonas hydrophila (100\%) and $A$. jandaei $(71 \%)$ were pathogenic for elvers: $L_{50}$ values were $10^{54}$ to $10^{7.5} \mathrm{cfu} \mathrm{fish}^{-1}$ (Table 2). Mortalities began at $18 \mathrm{~h}$ post-challenge, and 'red fin disease' as described by Rickards (1978) was produced in elvers that died during the experiment. Pure cultures of the inoculated $A$. hydrophila and $A$. jandaei strains were recovered from kidney and liver of all dead and moribund eels. In contrast, only $16 \%$ of these strains of motile Aeromonas spp. produced mortalities in the groups of challenged trout $\left(\mathrm{LD}_{50}\right.$ values ca $10^{7} \mathrm{cfu}$ fish $^{-1}$ ) (data not shown).

Table 2. Virulence of strains of various bacteria isolated from eels and eel farm water during epizootics as determined in Anguilla anguilla elvers by IP challenge. E: diseased glass eel; EA: diseased silver eel (gills); EO: diseased silver eel (liver); A: asymptomatic glass eel; AO: asymptomatic silver eel (liver); TW: tank water. Virulence on a scale from not virulent' $(-)$ to 'very virulent' $(+++)$

\begin{tabular}{|c|c|c|}
\hline $\begin{array}{c}\text { Species } \\
\text { Strain }\end{array}$ & Virulence & $\begin{array}{c}\mathrm{LD}_{50} \\
\left(\mathrm{cfu} \mathrm{fish} \mathbf{f i}^{-1}\right)\end{array}$ \\
\hline \multicolumn{3}{|l|}{ Aeromonas hydrophila } \\
\hline EO-63 (replicate 1) & +++ & $10^{5.4}$ \\
\hline EO-63 (replicate 2) & $++t$ & $10^{5.6}$ \\
\hline EA-59 & ++ & $10^{63}$ \\
\hline EO-64 & ++ & $10^{6.2}$ \\
\hline EA-68 & ++ & $10^{6.4}$ \\
\hline E-37 (replicate 1 ) & + & $10^{7.0}$ \\
\hline E-37 (replicate 2) & + & $10^{7.1}$ \\
\hline A-19 (replicate 1) & ++ & $10^{6.5}$ \\
\hline A-19 (replicate 2) & + & $10^{7.1}$ \\
\hline TW-1 & + & $10^{7.2}$ \\
\hline \multicolumn{3}{|l|}{ Aeromonas jandaei } \\
\hline$E-273$ & t+ & $10^{66}$ \\
\hline E-30 (replicate 1 ) & ++ & $10^{6.3}$ \\
\hline E-30 (replicate 2) & + & $10^{69}$ \\
\hline $\mathrm{AO}-60$ & t+ & $10^{6.4}$ \\
\hline $\mathrm{AO}-62$ & + & $10^{75}$ \\
\hline TW-9 (replicate 1) & + & $10^{74}$ \\
\hline TW-9 (replicate 2) & + & $10^{70}$ \\
\hline E-44 & - & $\geq 10^{84}$ \\
\hline A-26 (replicate 1) & - & $\geq 10^{8.6}$ \\
\hline A-26 (replicate 2) & - & $\geq 10^{83}$ \\
\hline \multicolumn{3}{|l|}{ Aeromonas sobria } \\
\hline A-13 & - & $\geq 10^{9.0}$ \\
\hline A-21 & - & $\geq 10^{8.4}$ \\
\hline TW-4 (replicate 1) & - & $\geq 10^{8.1}$ \\
\hline TW-4 (replicate 2) & - & $\geq 10^{79}$ \\
\hline \multicolumn{3}{|c|}{ Pseudomonas fluorescens } \\
\hline E-294 & - & $\geq 10^{8.2}$ \\
\hline E-280 & - & $\geq 10^{8.3}$ \\
\hline \multicolumn{3}{|c|}{ Shewanella putrefaciens } \\
\hline EO-89 & - & $\geq 10^{8.3}$ \\
\hline
\end{tabular}

Of the strains recovered from tank water and from eels in absence of disease, those of the species Aeromonas hydrophila (100\%), one of Vibrio anguillarum (25\%), and one of Pseudomonas fluorescens (20\%) were virulent for challenged elvers. A. hydrophila strains displayed $L_{50}$ values of $10^{6.2}$ to $10^{7.4} \mathrm{cfu} \mathrm{fish}^{-1}$, and the virulent strains of $V$. anguillarum and $P$. fluorescens showed $L_{50}$ values of $10^{7.3} \mathrm{cfu} \mathrm{fish}^{-1}$ (Table 3 ). Mortalities began at $2 \mathrm{~d}$ post-challenge. The bacteria were recovered from the kidneys and livers of all dead and moribund challenged elvers. External clinical signs in these fish included cutaneous petechiation on the ventral portions of the body and occasionally ulcerations. These strains were non-pathogenic for trout $\left(\mathrm{LD}_{50}\right.$ values were $\geq 10^{8} \mathrm{cfu} \mathrm{fish}^{-1}$ ) (data not shown).

Table 3. Virulence of strains of various bacteria isolated from eels and eel farm water during routine surveys as determined in. Anguilla anguilla elvers by IP challenge. S: healthy glass eel; SA: healthy silver eel (gills); SO: healthy silver eel (liver); TW: tank water. Virulence scale as in Table 2

\begin{tabular}{|c|c|c|}
\hline $\begin{array}{c}\text { Species } \\
\text { Strain }\end{array}$ & Virulence & $\begin{array}{c}\mathrm{LD}_{50} \\
\left.(\mathrm{cfu} \mathrm{fish})^{-1}\right)\end{array}$ \\
\hline \multicolumn{3}{|l|}{ Aeromonas hydrophila } \\
\hline S-188 (replicate 1 ) & +t & $10^{6.5}$ \\
\hline S-188 (replicate 2 ) & t+ & $10^{6.2}$ \\
\hline TW -170 & ++ & $10^{5.8}$ \\
\hline SO-324 (replicate 1 ) & + & $10^{7.2}$ \\
\hline SO-324 (replicate 2) & + & $10^{7.4}$ \\
\hline \multicolumn{3}{|l|}{ Aeromonas jandaei } \\
\hline SO-337 (replicate 1) & - & $10^{8.4}$ \\
\hline SO-337 (replicate 2) & + & $10^{76}$ \\
\hline \multicolumn{3}{|l|}{ Aeromonas sobria } \\
\hline SA-253 (replicate 1) & - & $\geq 10^{8.6}$ \\
\hline SA-253 (replicate 2) & - & $10^{8.0}$ \\
\hline \multicolumn{3}{|l|}{ Aeromonas caviae } \\
\hline$S-184$ & - & $\geq 10^{87}$ \\
\hline SA-251 & - & $\geq 10^{8.1}$ \\
\hline $\mathrm{SO}-314$ & - & $\geq 10^{8.7}$ \\
\hline \multicolumn{3}{|l|}{ Pseudomonas fluorescens } \\
\hline $\mathrm{SO}-317$ & + & $10^{73}$ \\
\hline S-220 (replicate 1 ) & - & $10^{8.6}$ \\
\hline S-220 (replicate 2) & - & $10^{80}$ \\
\hline $\mathrm{S}-355$ & _ & $10^{83}$ \\
\hline SA-306 & - & $\geq 10^{82}$ \\
\hline $\mathrm{SO}-332$ & - & $\geq 10^{82}$ \\
\hline \multicolumn{3}{|l|}{ Shewanella putrefaciens } \\
\hline TW-172 (replicate 1) & - & $\geq 10^{83}$ \\
\hline TW-172 (replicate 2) & - & $\geq 10^{77}$ \\
\hline \multicolumn{3}{|l|}{ Plesiomonas shiqelloides } \\
\hline $\mathrm{SO}-328$ & - & $\geq 10^{8.5}$ \\
\hline SO-334 (replicates 1 and 2) & - & $\geq 10^{8.7}$ \\
\hline \multicolumn{3}{|l|}{ Vibrio anquillarum } \\
\hline TW-157 & + & $10^{73}$ \\
\hline TW-137 & _ & $\geq 10^{8.3}$ \\
\hline TW-139 & - & $\geq 10^{8.4}$ \\
\hline TW-151 & - & $10^{8.0}$ \\
\hline
\end{tabular}


Bacteria were not present in samples from survivors, and mortalities did not occur in the control groups injected with sterile PBS.

A positive relationship was found between virulence of the isolates for elvers and their origin $\left(\chi^{2}\right.$ test $=5.013$, $\left.\mathrm{p}_{(\mathrm{n}=1)}<0.05\right)$. This result indicates that strains isolated during epizootics tended in general to be more virulent than those recovered in the absence of disease. This finding could be explained by the higher prevalence of Aeromonas hydrophila and A. jandaei in samples during epizootics.

\section{Bath challenges}

Mortalities in the bath challenge experiments began at 9 to $13 \mathrm{~d}$ post-challenge, depending on challenge received. There was a 17 to $34 \%$ mortality in elvers exposed to certain of the Aeromonas hydrophila strains and a 17 to $50 \%$ mortality in elver groups challenged with one of the $A$. jandaei strains (Table 4). All moribund fish showed ulcerations on the tail, and purulent liquid in the gills. In one case, petechiation of the fins was also detected. Internally, signs of infection were lacking. Large numbers of the bacteria used for the challenge were obtained on TSA-1 from the ulcers of freshly dead fish. They were also isolated from liver as pure cultures but in low numbers. In most cases, bacteria were not recovered from liver or incipient cutaneous lesions from the survivors (Table 4). Mortalities were not recorded in the group of elvers challenged with sterile TSB-1.

Table 4. Aeromonas hydrophila and A. jandaei. Mortality of Anguilla anguilla elvers following immersion challenges with selected strains. Symbols as in Tables $2 \& 3$

\begin{tabular}{|c|c|c|c|c|c|c|}
\hline \multirow{2}{*}{$\begin{array}{l}\begin{array}{l}\text { Species } \\
\text { Strain }\end{array} \\
\text { A. hydrophila }\end{array}$} & $\begin{array}{l}\text { Bacterial dose } \\
\quad(\text { cfu ml-1) }\end{array}$ & \multicolumn{2}{|c|}{ Mortality } & \multicolumn{2}{|c|}{$\begin{array}{l}\text { Reisolation } \\
\text { Dead Survivor }\end{array}$} & $\begin{array}{l}\text { Time to } \\
\text { death (d) }\end{array}$ \\
\hline & & & & & & \\
\hline $\mathrm{EO}-63$ & $\begin{array}{l}4.8 \times 10^{8} \\
1.7 \times 10^{7}\end{array}$ & $\begin{array}{l}2 / 6 \\
1 / 6\end{array}$ & $\begin{array}{l}34 \\
17\end{array}$ & $\begin{array}{l}2 / 2 \\
1 / 1\end{array}$ & $\begin{array}{l}0 / 4 \\
0 / 5\end{array}$ & $\begin{array}{l}10 \\
13\end{array}$ \\
\hline EA-68 & $\begin{array}{l}2.7 \times 10^{8} \\
2.0 \times 10^{7}\end{array}$ & $\begin{array}{l}1 / 6 \\
0 / 6\end{array}$ & $\begin{array}{r}17 \\
0\end{array}$ & $\begin{array}{c}1 / 1 \\
-\end{array}$ & $\begin{array}{l}0 / 5 \\
0 / 6\end{array}$ & $\begin{array}{l}9 \\
-\end{array}$ \\
\hline EA-59, S-188 & $\begin{array}{l}1.3 \times 10^{8} \\
4.2 \times 10^{7}\end{array}$ & $\begin{array}{l}0 / 6 \\
0 / 6\end{array}$ & $\begin{array}{l}0 \\
0\end{array}$ & - & $\begin{array}{l}0 / 6 \\
0 / 6\end{array}$ & - \\
\hline $\begin{array}{c}\text { A. jandaei } \\
\text { E-273 }\end{array}$ & $\begin{array}{l}5.0 \times 10^{8} \\
4.4 \times 10^{7}\end{array}$ & $\begin{array}{l}0 / 6 \\
0 / 6\end{array}$ & $\begin{array}{l}0 \\
0\end{array}$ & - & $\begin{array}{l}0 / 6 \\
0 / 6\end{array}$ & - \\
\hline $\mathrm{AO}-60$ & $\begin{array}{l}3.0 \times 10^{8} \\
1.2 \times 10^{7}\end{array}$ & $\begin{array}{l}3 / 6 \\
1 / 6\end{array}$ & $\begin{array}{l}50 \\
17\end{array}$ & $\begin{array}{l}3 / 3 \\
1 / 1\end{array}$ & $\begin{array}{l}0 / 3 \\
5 / 5^{\mathrm{a}}\end{array}$ & $\begin{array}{r}9 \\
11\end{array}$ \\
\hline
\end{tabular}

\section{DISCUSSION}

The infectivity experiments reported here demonstrate that Aeromonas hydrophila and A. jandaei strains isolated from the European eels in 1987-1988 were the cause of the eel disease originally reported to be the result of a mixed septicaemia by Esteve \& Garay (1991). These results are in agreement with those of Rickards (1978) and Kou (1981) who recognized the species A. hydrophila as an important pathogen for Japanese eels in Japan and Taiwan.

Challenged eels were resistant to strains of Pseudomonas fluorescens (2) and Shewanella putrefaciens (1) that had been isolated from diseased eels along with the mentioned Aeromonas species (Esteve \& Garay 1991). At various times, the species $P$. fluorescens and S. putrefaciens have been considered as fish spoilage organisms (Gillespie 1981) or as trout (Roberts \& Horne 1978) or rabbitfish (Saeed et al. 1987) pathogens. Our data indicate that they probably represented secondary invaders that took advantage of damaged eel tissues.

Isolation of Aeromonas jandaei from eels and water has not been reported previously. This species has recently been described by Carnahan et al. (1991) from human infections. Identification of $A$. jandaei isolates was a difficult problem because their phenotypic characteristics are very similar to those of the species A. sobria (Carnahan et al. 1991). Many A. jandaei strains from fish were elastase positive as well as pathogenic, whereas none of the tested $A$. sobria isolates was positive for these features. Thus, it should be kept in mind that virulent and elastase positive strains of $A$. sobria may actually correspond to $A$. jandaei strains. In fact, it is generally accepted that $A$. sobria is relatively non-pathogenic for fish, and there are very few reports of epizootics associated with $A$. sobria (Toranzo et al. 1989).

In the present study, disease produced by Aeromonas hydrophila/A. jandaei was induced by injection as well as by waterborne exposure. The disease was acute in eels infected by IP challenge, whereas it produced lower mortality rates and progressed more slowly when bath challenge was used. Although water transmission of the disease has been demonstrated with both of these species, we consider that water is not likely to be an important reservoir of these species because low numbers of Aeromonas spp. (approximately $18 \mathrm{cfu}$ per $100 \mathrm{ml}$ ) were always found in tank water (Esteve \& Garay 1991). In contrast, Aeromonas species were much more numerous in fish (Esteve \& Garay 1991), 
A. hydrophila and A. jandaei being especially abundant in eels during the epizootics. Some authors (Cahill 1990) have found that Aeromonas species occur in the gastrointestinal tract of salmonids and warm-water fish.

The eel disease showed a seasonal occurrence, appearing only in the warmest months when water temperatures increased from 17 to $21^{\circ} \mathrm{C}$. These temperatures are close to that described as optimal for European eels (Gault 1986). Mellergaard \& Dalsgaard (1987) reported that outbreaks caused by Aeromonas hydrophila in European eel farms in Denmark were always associated with fish grading and poor water quality, but these conditions did not appear to explain the epizootics studied by us (Esteve \& Garay 1991). On the other hand, it is well established that temperature influences the pathogenicity of $A$. hydrophila (Groberg et al. 1978, Schubert \& Matzinou 1990) because its ability to produce cytotoxins, hemolysin and enterotoxins is much higher at temperatures of $22{ }^{\circ} \mathrm{C}$ than at 4 to $10^{\circ} \mathrm{C}$ (Krovacek et al. 1991). In fact, most of our Aeromonas strains proved to be non-pathogenic for trout held at temperatures of only 13 to $15^{\circ} \mathrm{C}$.

In conclusion, the role of Aeromonas hydrophila and A. jandaei as primary pathogens for European eels is supported by their ability to reproduce disease in the eels under laboratory conditions using 2 challenge methods: IP injection and bath exposure. Moreover, the results obtained in these experiments suggest that Pseudomonas fluorescens and Shewanella putrefaciens act as opportunistic pathogens of European eels.

Acknowledgements. C.E. and E.G.B. thank the Ministerio de Educación y Ciencia (Spanish Government) and the Consellería de Cultura, Educación y Ciencia (Generalitat Valenciana) for their research fellowships. We thank A. E. Toranzo for her collaboration in the virulence assays on trout, R. Ruano (Conselleria de Medio Ambiente, Generalitat Valenciana) for supplying the elvers for the virulence assays, and E. Alcaide and A. J. Velazquez de Castro for their comments on the manuscript.

\section{LITERATURE CITED}

Austin, B., Austin, D. A. (1987). Bacterial fish pathogens, disease in farmed and wild fish. Ellis Horwood Ltd, Chichester

Baxa, D. V., Groff, J. M., Wishkovsky, A., Hedrick, R. P. (1990). Susceptibility of nonictalurid fishes to experimental infection with Edwardsiella ictaluri. Dis. aquat. Org. 8: 113-117

Biosca, E. G., Amaro, C., Esteve, C., Alcaide, E., Garay, E. (1991). First record of Vibrio vulnificus biotype 2 from diseased European eel, Anguilla anguilla L. J. Fish Dis. 14: $103-109$

Cahill, M. M. (1990). Bacterial flora of fishes: a review. Microb. Ecol. 19: 21-41

Carnahan, A., Fanning, G. R., Joseph, S. W. (1991). Aero- monas jandaei (formerly genospecies DNA group 9 A. sobria), a new sucrose-negative species isolated from clinical speciments. J. clin. Microbiol. 29: 560-564

Esteve, C., Garay, E. (1991). Heterotrophic bacterial flora associated with European eel Anguilla anguilla reared in freshwater. Nippon Suisan Gakk. 57: 1369-1375

Esteve, C., Garay, E. (1992). Numerical taxonomy of Vibrionaceae and Aeromonadaceae strains from water and fish. In: Schindler, J. (ed.) Proc. Conference on Taxonomy and Automated Identification of Bacteria. Czech Soc. Microbiol., Prague, p. 33-36

Gault, J. (1986). L'élevage de l'anguille. In: Bernabé, G. (ed.) Aquaculture, Vol. II, Technique et documentation. Lavoisier, Paris, p. 742-771

Gillespie, N. C. (1981). A numerical taxonomy study of Pseudomonas-like bacteria isolated from fish in Southeastern Queensland and their association with spoilage. J. appl. Bacteriol. 50: 29-44

Groberg, W. J., McCoy, R. H., Pilcher, K. S., Fryer, J. L. (1978). Relation of water temperature to infections of coho salmon (Oncorhynchus kisutch), chinook salmon (O. tshawytscha), and steelhead trout (Salmo gairdneri) with Aeromonas salmonicida and A. hydrophila. J. Fish. Res. Bd Can. 35: $1-7$

Jensen, N. J., Larsen, J. L., Christensen, N. O. (1983). Spring ulcer disease in eel (Anguilla anguilla). Diseases of commercially important marine fish and shellfish. Rapp. P.-v. Réun. Cons. int. Explor. Mer 182: 106-110

Kou, G. H. (1981). Some bacterial diseases of eel in Taiwan. Proc. Republic of China, NSC Symposium Series No. 3

Krovacek, K., Faris, A., Mansson, I. (1991). Growth of and toxin production by Aeromonas hydrophila and Aeromonas sobria at low temperatures. Int. J. Food Microbiol. 13: $165-176$

MacCarthy, D. H. (1976). Vibrio disease in eels. J. Fish Biol. 8: $317-320$

Markward, N. M., Klontz, G. W. (1989). Evaluation of four methods to establish asymptomatic carriers of Aeromonas salmonicida in juvenile spring chinook salmon, Oncorhynchus tshawytscha (Walbaum). J. Fish Dis. 12: 311-315

Mellergaard, S., Dalsgaard, I. (1987). Disease problems in Danish eel farms. Aquaculture 67: 139-146

Michel, C., Bernardet, J.-F. (1991), Identification and phenotypic characterization of Pseudomonas anguilliseptica strains isolated from farmed European eel Anguilla anguilla in France. In: Bernoth, E.-M. (ed.) Diseases of fish and shellfish. Eur. Ass. Fish Pathol., Budapest, p. 185

Nakai, T., Muroga, K. (1982). Pseudomonas anguilliseptica isolated from European eels (Anguilla anguilla) in Scotland. Fish Pathol. 17: 147-150

Palleroni, N. J. (1984). Genus I. Pseudomonas Migula 1894, $237^{\text {AL }}$ (Nom. cons. Opin. 5, Jud. Comm. 1952, 237). In: Krieg, N. R., Holt, J. G. (eds.) Bergey's manual of systematic bacteriology, Vol. 1, Section 4. 9th edn. Williams \& Wilkins, Baltimore, p. 141-198

Reed, M. J., Müench, M. (1938). A simple method for estimating fifty percent endpoints. Am. J. Hyg. 27: 493-497

Rickards, W. L. (ed.) (1978). A diagnostic manual of eel diseases occurring under culture condition in Japan. Sea Grant Publication UNC-SG-78-06. UNC Sea Grant, Raleigh

Roberts, R. J., Horne, M. T. (1978). Bacterial meningitis in farmed rainbow trout, Salmo gairdneri Richardson, affected with chronic pancreatic necrosis. J. Fish Dis. 1: $157-164$

Saeed, M. O., Alamoudi, M. M., Al-Harbi, A. H. (1987). A 
Pseudomonas associated with disease in cultured rabbitfish Siganus rivulatus in the Red Sea. Dis. aquat. Org. 3: $177-180$

Santos, Y., Toranzo, A. E., Barja, J. L., Nieto, T. P., Vila, T. G. (1988). Virulence properties and enterotoxin production of Aeromonas strains from fish culture systems. Infect. Immun. 56: 3285-3293

Schubert, R. H. W., Matzinou, D. (1990). Temperature as an environmental factor influencing the pathogenicity of

Responsible Subject Editor: T. Evelyn, Nanaimo, B.C., Canada
Aeromonas hydrophila. Zbl. Bakt. Parasitkde 273: $327-331$

Thampuran, N., Lyer, K. M. (1989). A note on the distribution of Alteromonas putrefaciens in marine fishes landed at cochin. J. Food Sci. Tech. 26: 166-168

Toranzo, A. E., Baya, A. M., Romalde, J. L., Hetrick, F. M. (1989). Association of Aeromonas sobria with mortalities of adult gizzard shad, Dorosoma cepedianum Lesueur. J. Fish Dis. 12: 439-448

Manuscript first received: March 25, 1992 Revised version accepted: April 27, 1993 